\title{
Rusijos-Baltarusijos karinis bendradarbiavimas: teorija ir praktika
}

\begin{abstract}
Šiame straipsnyje nagrinejjama Rusijos ir Baltarusijos karinio bendradarbiavimo dinamika, kai Rusijos agresija Ukrainoje pademonstravo prezidento Vladimiro Putino siekį visomis įmanomomis priemonèmis užsitikrinti savo interesų zonos kontrolę artimiausioje posovietinejje erdvejje. Galime kalbėti apie karinio bendradarbiavimo patvarumo gilinimo laikotarpi, kuriame Rusija demonstruoja principinę nuostatą išplèsti karinių pajegumų panaudojimo galimybes pasiremiant Baltarusijos karinėmis pajègomis, karine infrastruktūra bei teritorija, kaip placdarmu galimiems potencialiems kariniams veiksmams. Todèl siekiama išsiaiškinti abiejų valstybių karinę integraciją lemiančius pagrindinius veiksnius: aptarti karinę politiką reglamentuojančiuose dokumentuose užfiksuotas karinio bendradarbiavimo kūrimo kryptis ir uždavinius, aptarti ir įvertinti karinių pajègų sąveikos didinimo praktinius atvejus (strateginès karinès pratybos), atskleisti karinio-techninio bendradarbiavimo pasiekimus ir problemas, galimas vystymosi perspektyvas.
\end{abstract}

\section{lvadas}

Baltarusijos-Rusijos santykiuose per tris dešimtmečius stabiliausiai sferai yra priskirtinas karinis bendradarbiavimas, nors abiejų valstybių tarpusavio sugyvenimas yra lydimas tariamų, inscenizuotų ir vis dar pasitaikančių nesutarimų ar trumpalaikès įtampos blyksnių, itin primenančių meteorų dangų nušviečiančius skrydžius nuodėmingos Žemès link. Prieš beveik dešimtmeti politologas Gražvydas Jasutis išsamiame tyrime Rusijos ir Baltarusijos karinị bendradarbiavimą įvardijo kaip karinị aljansą, kadangi ilgamečiai dvišaliai santykiai karinejje srityje nuo veiklos koordinavimo perèjo visus keturis sudètinius karinès integracijos etapus: teisinị-sutartinị, institucinị, instrumentinị ir funkcinès priklausomybès srityje, t. y. pasiekè aukščiausiajj karinès integracijos etapą.

Jo nuomone, ,šio aljanso dezintegracija mažai tikètina, nes valstybių karinès pajègos yra pasiekusios aukštą sąveikumo laipsnị ir sukurtos struktūros

\footnotetext{
${ }^{*}$ Dr. Virgilijus Pugačiauskas - Generolo Jono Žemaičio Lietuvos karo akademijos Politikos mokslų katedros profesorius. Adresas korespondencijai: Šilo g. 5A, 10322 Vilnius, tel. (8 5) 210 3582,

el. p.: virgilijus.pugaciauskas@lka.lt
} 
iš dalies prisideda prie integracijos gilinimo. Ekonominiai ir politiniai Rusijos ir Baltarusijos nesutarimai neturi lemiamos įtakos karinio aljanso raidai. Ivvertinus vidinius ir išorinius veiksnius, tikètina, kad Rusijos ir Baltarusijos karinis aljansas vidutineje perspektyvoje ne tik dominuos posovietineje erdveje, bet ir stiprès. “' Šis vertinimas skirtas situacijai, kai Rusijos ir Vakarų pasaulis gyvavo tam tikrą pozityvių santykių laikotarpị, todèl būtų tikslinga aptarti, ar Rusijos konfrontacijos su Vakarais kontekste galime fiksuoti naujus pokyčius ir galimas naujas perspektyvas.

Šiame straipsnyje keliamas tikslas - išanalizuoti Rusijos ir Baltarusijos karinio bendradarbiavimo dinamiką, kai Rusijos agresija Ukrainoje pademonstravo prezidento Vladimiro Putino siekị visomis įmanomomis priemonėmis užsitikrinti savo interesų zonos kontrolę posovietinėje erdvėje. Rusijos karinès galios didinimo strategija ir jos pagalba konstruojami santykiai su Vakarais natūraliai padidino Baltarusijos geopolitinę svarbą ir karinę strateginę reikšmę. Dèl savo geostrateginès padèties (sausumos siena beveik tūkstantis kilometrų ir $200 \mathrm{~km}$ iki Kaliningrado karinio forposto) Baltarusija yra svarbi kaip vadinamoji „buferio zona“2, skirianti Rusiją nuo Vakarų ir sauganti pastarosios teritoriją. Pasak Baltarusijos prezidento Aleksandro Lukašenkos, „Vakarų kryptyje Baltarusija yra pagrindinis forpostas, įskaitant ir Rusijos" ${ }^{\text {“3. }}$ Rusijai pradejus karą su Vakarais, Baltarusija taip pat būtų svarbi karinių pajègų sutelkimo teritorija ir puolamosios operacijos ị Vakarus išeities rajonas. Dèl savo artumo su Kaliningradu, Baltarusija tampa ypatingos svarbos teritorija Rusijai nusprendus deblokuoti ši Vakarų apsuptą anklavą ir užtikrinti susisiekimą su juo sausuma. Dèl minètų priežasčių Rusija yra ypač suinteresuota stiprinti savo įtaką Baltarusijoje, kuri kaskart demonstruoja turinti teisę ì skirtingą nuomonę, nesutampančia su pagrindinio sąjungininko vykdoma politika. Būtent pastaraisiais metais išryškèjo Rusijos pastangos gilinti integracinị procesą, remiantis Rusijos-Baltarusijos sąungos egzistavimu bei tvarumu ir karinio bendradarbiavimo stiprinimu.

Todèl šiame straipsnyje ieškosime atsakymų ị klausimus: kokie yra nau-

\footnotetext{
${ }^{1}$ Jasutis G., (2011). Karinio aljanso patvarumo tyrimas: Rusijos ir Baltarusijos atvejis. Daktaro disertacija. Vilnius: Vilniaus universitetas. p. 33-48, 137.

${ }^{2}$ Colibasanu A., Russia, Belarus and a Catch-22. https://geopoliticalfutures.com/russia-belarus-catch-22/; Fedirka A., Belarus: Between a Rock and a Hard Place, Geopolitical futures, https://geopoliticalfutures. com/belarus-between-a-rock-and-a-hard-place [žiūrèta 201802 03]; Kłysiński K., Żochowski P., The End Of The Myth of a brot herly Belarus? Russian soft power in Belarus after 2014: the background and its manifestations, OSW Studies, 2016, s. 47-49 arba https://www.osw.waw.pl/en/publikacje/osw-studies/2016-11-07/end-myth-a-brot-herly-belarus-russian-soft-power-belarus-after [žiūrèta 201802 05]. ${ }^{3}$ Президент раскритиковал нежелание России укреплять армию Беларуси и других членов ОДКБ, https://news.tut.by/economics/580911.html [žiūrèta 201802 05].
} 
ji šalių karinio bendradarbiavimo planai, ar karinė integracijos patiria ryškių pokyčiu, kokia galima jos perspektyva trumpuoju laikotarpiu? Susikoncentruosime ị du esminius sudètinius karinès integracijos elementus: bendras karines pratybas ir karinị-techninị bendradarbiavimą.

\section{Kariniu pajėgu sąveikos strategija, taktika ir praktika}

Rusijos-Baltarusijos karinis bendradarbiavimas atsispindi ir abiejų šalių pagrindiniuose karinès politikos dokumentuose - doktrinose. Štai $2014 \mathrm{~m}$. Rusijos karinëje doktrinoje nurodoma, kad Sajunginès valstybės karinio užpuolimo atveju, Rusija vertins tai kaip agresiją ir iggyvendins atsakomąsias priemones, be to, itvirtinamas karinio bendradarbiavimo su Baltarusija prioritetas, apimantis nacionalinių pajegų vystymo koordinavimą ir karinès infrastruktūros panaudojimą bei bendros valstybès gynybos sukūrimą, remiantis Bendros valstybès karine doktrina ${ }^{4}$. Taigi išimtinai koncentruojamasi ị Rusijos karinių jègų panaudojimo sąlygų užtikrinimą kaimyninèje valstybejje.

Savo ruožtu Baltarusijos naujoje doktrinoje santykiams karineje srityje su Rusija yra skirtas gerokai didesnis dėmesys. Labiausiai detalizuojamas vieningų regioninių karinių pajègų vaidmuo bendroje saugumo dimensijoje, kaip antai, numatomi vieningi veiksmai su Rusija, siekiant užtikrinti bendros valstybės saugumą karinès agresijos atveju, ir sudarymas sąlygų jai veikti, karinès jègos panaudojimas bendros valstybės gynimui reglamentuojamas sutartimis su Rusija, vieningų regioninių karinių pajėgų valdymui „didėsiančios grèsmès akivaizdoje“, sukuriama kolegiali karinè institucija ir numatomas gynybinio sektoriaus kooperacinių ryšiu vystymas ${ }^{5}$. Matome, kad Baltarusijos doktrinoje bendras karinių pajęų veikimas apibrèžiamas tiksliau, nustatant atvejus ir procedūras dèl vieningų regioninių karinių pajègų panaudojimo, tuo tarpu Rusija užpuolimo atveju naudoja karinę jègą savo nuožiūra. Taigi požiūrio skirtumas dèl bendros šalių gynybos yra labiau nei akivaizdus.

\footnotetext{
${ }^{4}$ Rusijos-Baltarusijos glaudus bendradarbiavimas posovietineje epochoje yra lydimas strateginiu sumanymu realizuoti Sąjunginès valstybės kūrimo idejją nuo pat 1992 m., tačiau procesas vyko lètai. Pastaruoju metu Rusija inicijavo 1999 m. pasirašytos Bendros valstybės sutarties praktinị igyvendinimą, siekdama užsitikrinti vis didesnę Baltarusijos vidaus ir užsienio politikos kontrolę. Šio viršvalstybinio darinio kompetencijai yra taip pat priskirtos bendros karinès funkcijos, apimančios vieningų regioninių karinių pajęgu sukūrimą, bendros gynybos politikos vystymą ir karinį-techninį bendradarbiavimą. Договор о создании Союзного государства, http://www.soyuz.by/about/docs/dogovor5/ [žiūrèta 201802 04]. Военная доктрина Российской Федерации, https://rg.ru/2014/12/30/doktrina-dok.html [žiūrèta $20180206]$.

${ }^{5}$ Военная доктрина Республики Беларусь, http://www.pravo.by/document/?guid=12551\&p0=H1160041 2\&p1=1 [žiūrèta 20180206 ].
} 
Karinio bendradarbiavimo procedūros yra ịvardytos Sąunginès valstybės $2001 \mathrm{~m}$. karinëje doktrinoje ir naujausia turètų įsigalioti $2019 \mathrm{~m}$., o jos turinys neatskleidžiamas. Pirmajame dokumente numatyti plačios apimties planai ir tokios pagrindinès veiklos kryptys: Rusijos ir Baltarusijos kariuomenių valdymo sistemų unifikacija, techninis nacionalinių karinių pajègų modernizavimas, remiantis bendromis programomis, taip pat bendros pratybos, karinès infrastruktūros, reikalingos bendram panaudojimui, vystymas. Doktrinos nuostatų igyvendinimo loginè tąsa yra sukūrimas dviejų karinių struktūrų - vieningos regioninės oro gynybos sistemos ir regioninès sausumos karinès grupuotès turinčių užtikrinti abiejų šalių ginkluotųjų pajėgų sąveiką konflikto su Vakarais atveju. Užtikrinant šiu struktūrų funkcionavimą numatyti ir konkretūs integraciją stiprinantys veiksmai - bendrų valdymo sistemų tobulinimas, mobilizacinių išteklių parengimas, unifikuotos techninès priežiūros ir logistinių bazių sistemos sukūrimas ${ }^{6}$. Naujojoje doktrinoje turètų būti deklaruotas naujas integracinis etapas, vedantis prie gilesnio abiejų karinių pajegų telkimo. Tiesą pasakius, šio dokumento pasirašymo procedūras vilkina Baltarusija, kadangi pagal sumanymą dokumentas turejo būti patvirtintas $2018 \mathrm{~m}$. pabaigoje, o Rusija realizavo visas reikiamas procedūras ${ }^{7}$.

Kalbant apie vieningų regioninių karinių pajègų sukūrimą, kaip prioritetinị bendradarbiavimo uždavinị, reikètų išsiaiškinti, kokios sąjungininkių karinès pajègos priskiriamos šiai grupuotei. Šiam kariniam junginiui, manytina, kad yra priskirtos visos Baltarusijos ginkluotosios pajègos ir Rusijos karinès pajegos, veikiančios vakarinèje jos dalyje, bei kiti Rusijos kariniai daliniai pagal numatytą planą. Šalių pajėgumai taikos metu yra pavaldūs savo karinėms vadovybèms. Tuo tarpu karo metu turètų būti suformuota bendra aukščiausio lygio vadovybé, kuri vadovautų abiejų šalių jungtinèms pajègoms. Prielaidą apie bendrų jungtinių pajegų formavimą ir sudètį patvirtina baltarusių ekspertas Nikita Dunec ${ }^{8}$, kurio manymu, Rusijos ir Baltarusijos grupuotei priklauso visos Baltarusijos karinès pajėgos ir Rusijos Vakarų karinès apygardos 20-oji armija su priskirtais centrinio ir regioninio lygmens valdymo padaliniais, o optimali kovinè sudètis nustatoma bendrų pratybų metu. Šiuo atveju Dunec

\footnotetext{
${ }^{6}$ Военная доктрина Союзного государства, https://www.postkomsg.com/documentation/document/472/ [žiūrèta 20180206 ].

${ }^{7}$ Путин одобрил проект военной доктрины Союзного государства, https://rg.ru/2018/12/19/putinodobril-proekt-voennoj-doktriny-soiuznogo-gosudarstva.html [žiūrèta 201802 07].

${ }^{8}$ Дунец Н. А., Военно-политические аспекты функционирования региональной группировки войск Беларуси и России, http://elib.bsu.by/bitstream/123456789/184865/1/Дунец_Истор_Ч.1-067-077. pdf. [žiūrèta 201802 09]; Соглашение между Российской Федерацией и Республикой Беларусь о совместном обеспечении региональной безопасности в военной сфере, http://www.mid.ru/foreign policy/international_contracts/2_contract/-/storage-viewer/bilateral/page-264/47455 [žiūrèta 201802 10].
} 
vertinimas dèl rusų grupuotès gali būti ne visai tikslus, kadangi po 2014 metų minètoji 20-oji armija galimai yra skirta igyvendinti Rusijos interesus Ukrainos kryptimi. Panašiau, kad karo atveju Baltarusijoje galètų veikti 2017 metai atkurta 1-oji tankų armija, kurios padaliniai yra išdėstyti gana arti Baltarusijos sienos.

Rusijos ir Baltarusijos karinis bendradarbiavimas labiausiai realizuojamas bendrose karinėse strateginėse pratybose, todèl yra tikslinga išsiaiškinti šių mokymų kiekybinius parametrus ir galimus potencialius kokybinius poslinkius. Nuo $2005 \mathrm{~m}$. pakaitomis kas dveji metai abiejų šalių teritorijose vyksta pratybos, plačiajai visuomenei žinomos „Sčyt Sojuza“ ir „Zapad“ pavadinimais. Po Rusijos ịvykdytos Krymo aneksijos 2015 metais Rusijos vakarinejje dalyje i̇vyko planinès pratybos „Sčyt Sojuza 2015“. Vakarų karinès apygardos Sankt Peterburgo ir Pskovo apylinkèse dalyvavo jungtinès pajègos - apie 8000 kariškių (tarp jų 1300 baltarusių) ir apie 400 karinès technikos vienetų, iskaitant aviaciją ir laivus. Pratybos sutelktos ị gynybinio mūšio su perẻjimu i puolimą veiksmams koordinuoti, igūdžiams tobulinti, vadovaujant jungtiniam štabui, taip pat buvo skiriamos šiuolaikinių ryšių priemonių suderinamumui ${ }^{9}$.

Nagrinejjant dviejų šalių karinę integraciją ir sąveiką, geriausiu ir naujausiu tyrimo objektu gali būti Rusijos-Baltarusijos strateginiai mokymai „Zapad 2017“. Anot oficialių šaltinių, pratybų tikslas - įvairaus lygmens štabų suderinamumo tobulinimas, naujų perspektyvinių kariuomenès ir ginklų valdymo sistemų susiejimas, naujų statutinių dokumentų aprobavimas, visų lygių karininkų praktika planuojant panašaus pobūdžio karines pratybas. Reikia pasakyti, kad manevrai Baltarusijoje tebuvo Rusijoje organizuotų didelių, apimančių visą vakarinę europinę Rusijos dalį, strateginių pratybų trečiojo etapo sudedamoji dalis. Taigi sąveiką liudija bendri koordinuoti abiejų šalių veiksmai. Baltarusijos teritorijoje manevruose dalyvavo apie 12 700, tarp jų 5500 Rusijos karių desantininkų, tankistų, lakūnų, ryšininkų ir pėstininkų, 70 lèktuvų ir sraigtasparnių, iki 680 karinès technikos, tarp kurių apie 250 tankų ir iki 200 artilerijos pabūklų, reaktyvinių sistemų ir minosvaidžių ${ }^{10}$. Reikètų

\footnotetext{
${ }^{9}$ Белялова Н., Российско-белорусские учения „Щит Союза“. Досье https://tass.ru/info/2248332 [žiūreta 201802 11]; Российско-белорусские учения „Щит Союза-2015“ стартуют на западе РФ https://ria.ru/20150910/1240961439.html [žiūrèta 201802 11]; Газета Министерства обороны Республики Беларусь „Белорусская военная газета. Во славу Родины“, https:/vsr.mil.by/2015/09/24/ po-glavnoj-magistrali\%e2\%80\%a6-svyaznoj [žiūrèta 201802 11]; Шойгу: подготовка к белорусскороссийскому учению „Щит Союза - 2019“ перешла в активную фазу http://www.soyuz.by/news/security/43547.html [žiūrèta 20180212 ].

${ }^{10}$ Учения „Запад-2017“: проверка „нервной системы“ российской армии, https://tass.ru/armiyai-opk/4573331 [žiūrèta 201802 11]; Легенды „Запада“. Что показали российско-белорусские стратегические учения 2017 года https://rg.ru/2017/09/20/chto-pokazali-rossijsko-belorusskie-ucheniiazapad-2017.html [žiūrèta 201802 11].
} 
pasakyti, kad pateikiama statistika gerokai skiriasi. Štai remiantis Baltarusijos gynybos ministerijos tarptautinio karinio bendradarbiavimo departamento viršininko generolo Olego Vojnovo pranešimu spaudai, manevruose dalyvavo 10175 Baltarusijos ir 3100 Rusijos kariškių (šiuo atveju turima omenyje dalyvavusius Baltarusijos teritorijoje), 138 tankai, iš jų 98 Rusijos, karinès transporto priemonės, atitinkamai artilerinių ir reaktyvinių sistemų 231 (104), lèktuvų ir malūnsparnių $49(27)^{11}$. Pratybose buvo išbandoma Rusijos ir Baltarusijos vieningoms regioninėms karinèms pajègoms ir vieningai regioninei oro gynybos sistemai priskirtų abiejų šalių pajègų gebejjimai veikti kartu. Nors pagrindinis pratybų veiksmas vyko Baltarusijoje, tačiau Rusijoje vykusios pratybos galimai turejo tiesioginių sąsajų su Baltarusijoje vykdyta veikla. Todèl reikètų pažymèti, kad oficiali statistika nèra patikima, ypač kai kalbama apie pratybas, vykusias Rusijos teritorijoje - realus karių ir kovos technikos skaičius kelis kartus viršijo deklaruotąji ${ }^{12}$. Reikia akcentuoti dar vieną svarbų pratybų momentą - Baltarusijos teritorijoje nuolatos dalyvauja kur kas didesnis skaičius Rusijos karinių dalinių nei Baltarusijos Rusijoje.

Baltarusijos teritorijoje pratybos organizuotos 8 poligonuose, proporcingai visoje šalies teritorijoje nuo Vitebsko iki Bresto. Juose abiejų šalių daliniai praktikavosi, anot oficialių pranešimų, vykdydami gynybines ir puolamąsias operacijas, susijusias su valstybès sienos, karinių objektų gynyba, priešo diversijų ir žvalgybos grupių, teroristinių grupuočių sunaikinimu bei gynybinio pobūdžio mūšio pratybomis. Čia svarbu dar kartą pabrěžti, kad vèl matome akivaizdžią disproporciją tarp deklaruojamų tikslų ir jiems igyvendinti naudojamų priemonių, t. y. pratybų metu teroristus naikina kariuomenė arba jos specialiụjų operacijų pajègos. Prieš lengvai ginkluotas ir negausias „teroristų“ grupeles, abiejų valstybių kariniai daliniai naudoja sunkiąją ginkluotę - tankus, aviaciją ir artileriją. Pažymètinas sutapimas - teroristinès grupelès dažnai veikia Lenkijos arba Lietuvos pusēje arba iš šių šalių veržiasi ị Baltarusiją ${ }^{13}$. Galima daryti prielaidą, kad treniruojamasi kovoti ne su teroristais ar nelegaliomis ginkluotomis formuotemis.

Objektyviai sunku ịsivaizduoti, kas iš šių pratybų oponentais minimų teroristų ir nelegalių karinių grupuočių turi pajègas, galinčias vykdyti puola-

\footnotetext{
"11 „Запад-2017“ Дневник белорусско-российских военных учений, https://naviny.by/ article/20170920/1505918347-zapad-2017-dnevnik-belorussko-rossiyskih-voennyh-ucheniy [žiūrèta $20180213]$

${ }^{12}$ Petraitis D., Zapad-2017 anatomija: kai kurie Rusijos karinio planavimo ypatumai, Lietuvos metine strateginé apžvalga 2017-2018, t. 19, p. 239-257; Grèsmių nacionaliniam saugumui vertinimas 2018, https://www.vsd.lt/wp-content/uploads/2018/03/LTU.pdf. [žiūrèta 201802 14].

${ }_{13}$ Условным противником на учениях «Запад-2017» будет белорусский регион, https://www.svoboda. org/a/28704972.html [žiūrèta 201802 15].
} 
muosius veiksmus teritorijoje nuo Sankt Peterburgo Rusijoje iki Bresto Baltarusijoje. Peršasi mintis, kad visai ne prieš teroristus ruošiasi kariauti ir ne nelegalių karinių grupuočių bazes ketina pulti bendras Rusijos ir Baltarusijos karinis mechanizmas, veikiantis tokiame strateginio dydžio karo teatre. Jungtinių pajegų naudojama ginkluotè ir pajègų dydis suponuoja mintị, kad numanomas (hipotetinis) rusų ir baltarusių oponentas yra skaitlingos ir techniškai pažangia ginkluote aprūpintos reguliariosios pajegos. Peršasi ir kita prielaida, pagrịsta dar Sakartvelo ir Ukrainos pavyzdžiais, kai puolamosios ginkluotès koncentravimo ir jos panaudojimo veiksmai treniruojami ne gynybai vykdyti, bet greitam ir trumpalaikiam ofenzyvinio tipo kariniam tikslui tgyvendinti.

Rusų ir baltarusių pratybų pokyčiai išryškẻja palyginus statistinius duomenis su ankstesnemis „Zapad 2013“ pratybomis. Dalyvaujančių karių skaičius didejja abiejose partnerių pusèse, tačiau labiau rusų. Karinès technikos skaičius, atsižvelgiant $\mathfrak{i}$ galimus neobjektyvius duomenis, buvo galima sakyti panašus, išskyrus sunkiosios ginkluotės, pvz., tankų, kurių skaičius padidejjo beveik dvigubai - nuo 78 iki 138. Kitas ryškus skirtumas - pratybų erdve, nuo dviejų poligonų, esančių prie Lietuvos ir Lenkijos sienų („Bresto“ ir „Gožos“ Gardino rajone), apėmė visą Baltarusijos teritoriją. Taigi planinių karinių pratybų mastas ir teritorija palaipsniui plečiasi ${ }^{14}$.

Reikia akcentuoti, kad sąveikos pokyčius liudija kitos dvišalès pratybos, ne ką mažiau svarbios, tačiau mažiau atspindètos žiniasklaidoje. 2017 m. nuo gegužès iki pat rugsèjo įvyko ịvairaus pobūdžio ir masto bendrų pratybų: gegužès 19-25 d. Baltarusijos teritorijoje radioelektroninès kovos pratybos su 1500 kariškių, rugpjūčio mėnesị logistikos pratybos dviem etapais: Baltarusijos teritorijoje 2500 vietinių kariškių ir 3000 Rusijos, vasaros mènesiais intensyvias pratybas vykdè inžinerinès, susisiekimo, tankų, cheminio ginklo ir oro erdvès gynybos daliniai. Pastarųjų atveju ị Baltarusijos aerodromus leidosi Rusijos lekktuvai ${ }^{15}$. Palyginus su ankstesnemis bendromis pratybomis, įvykusiomis iki 2014 m., matome ryškų mokymo masto padidejjimą. Taigi pratybų eiga pasižymi nuolatiniu intensyvumu - be ịprastinio „Sčyt Sojuza-2019“ ir joms skirtų tarpinių parengiamųjų pratybų, nuo $2015 \mathrm{~m}$. kasmet vykdomos abiejų valstybių specialių pajegų pratybos, nacionalinès ir dvišalès parengiamosios pratybos.

\footnotetext{
${ }^{14}$ Rusija informacijos apie „Zapad 2013“ siūlo ieškoti ministerijos tinklalapyje http://www.diena.lt/naujienos/lietuva/politika/rusija-informacijos-apie-zapad-2013-siulo-ieskoti-ministerijos tinklalapyje-414901 [žiūrèta 201802 20].

${ }^{15}$ Wilk A., The Zapad-2017 exercises: the information war (for now), Centre for Eastern studies, https:// www.osw.waw.pl/en/publikacje/osw-commentary/2017-09-04/zapad-2017-exercises-information-warnow], [žiūrèta 201802 22].
} 
Baltarusijos politinè ir karinė valdžia nuolatos akcentuoja, kad vystomi tik gynybiniai pajègumai ir kariuomenè rengiasi tik savo ir sąungininkès Rusijos gynybai ${ }^{16}$. Šiuo atveju reiktų išsiaiškinti, kokiai tariamai gynybai ruošiasi Baltarusijos ginkluotosios pajėgos ir kaip vyktų sąveika su sajungininku. Šalies karinė vadovybė prioritetu laiko specialiųjų operacijų pajėgų (SOP) ir specializuotų padalinių, tokių kaip elektroninės kovos, signalų žvalgybos ir naujos kartos ryšių sistemų padalinių kūrimą. Jiems yra skiriamas didesnis finansavimas ir teikiama pirmenybė aprūpinant reikiama įranga, ginkluote ir technika. Baltarusijos SOP ir specializuotiems padaliniams keliami tokie reikalavimai kaip mobilumas ir greiti veiksmai, gebèjimas patiems vykdyti veiksmus priešo kontroliuojamoje teritorijoje. Baltarusijos ginkluotujų pajėgų kovinis rengimas rodo, kad ginkluotosios pajègos yra ruošiamos kariauti sudėtingomis sąlygomis naujo tipo karus, kuriuose gerokai išauga specialiųų operacijų pajègų reikšmè. Kaip paramos elementas specialiųų operacijų pajègoms lygiagrečiai yra vystomi ir jas paremti mūšyje galintys kiti pajègumai, pvz., aviacija ir artilerija - 2017-2018 m. baltarusiai ịsigijo naujų sraigtasparnių „Mi-8MTV-5“, orlaivių „Jak-130“, sukūrè ir prièmė ị ginkluotę reaktyvinę salvinę ugnies sistemą „Polonez“, galinčią naikinti taikinius $300 \mathrm{~km}$ atstumu. ${ }^{17}$

Baltarusijos pajègų dislokavimo vietų ir poligonų išdèstymas taip pat nurodo hipotetini priešą. Kariniai daliniai yra išdèstyti šitaip: trys iš sausumo pajėgų brigadų ir dvi iš trijų SOP brigadų yra dislokuotos Gardino, Slonimo, Bresto, Marjina Gorkos ir Minsko vietovèse. Šios vietovès yra Vakarų ir centrinejje Baltarusijos dalyse netoli sienos su Lenkija ir Lietuva. Pagrindiniai Baltarusijos kariuomenès pratybų metu naudojami kariniai poligonai (Borisovo, Obuz-Lesnovsko, Gožos) taip pat yra vakarinejje ir centrinejje šalies dalyje ${ }^{18}$. Akivaizdu, kad jų veiksmų rajonai užtikrina Rusijos pajėgų apsaugą ir jų pasirengimą veiksmams, nukreiptiems prieš Vakarus, ir tai atitinka Rusijos ir Baltarusijos turimus susitarimus dèl bendrų veiksmų gynybos srityje ${ }^{19}$.

Atlikus Baltarusijos pajègų išsidèstymo, struktūros ir vystymosi tendencijų analizę galima teigti, kad hipotetinio Rusijos ir NATO karo atveju Baltarusijos ka-

\footnotetext{
${ }^{16}$ Гучек М., Лукашенко обещает России поддержку армии на западном направлении, https://ria.ru/ world/20161007/1478723524.html [žiūrèta 201802 30].

${ }^{17}$ Grèsmių nacionaliniam saugumui vertinimas 2018, https://www.vsd.lt/wp-content/uploads/2018/03/ LTU.pdf; [žiūrèta 201802 14].

${ }_{18}$ Украинская оценка состояния и перспектив белорусской армии, https://bmpd.livejournal. com/2878328.html, [žiūrèta 201803 02]; Карта расположения частей ВС Белоруссии, https://armijarossii.blogspot.com/2014/03/blog-post_9.html\#!/2014/03/blog-post_9.html [žiūrèta 201803 02].

${ }^{19}$ Решение Высшего Совета Сообщества Беларуси и России от 02.04.1997 N 5. „Об Общих принципах военного строительства и использования элементов военной инфраструктуры Беларуси и России“. http://lawru.info/dok/1997/04/02/n104196.html [žiūrèta 201803 02]; Решение № 4 Высшего Совета Союза Беларуси и России. О Концепции совместной оборонной политики Беларуси и России. http://www.conventions.ru/view_base.php?id=14630 [žiūrèta 20180302 ].
} 
riuomenè galimai atliktų Rusijos priešakinių pajègų (avangardo) žvalgybos ir apsaugos elemento funkcijas. Galimos jos užduotys - saugoti, aprūpinti ir užtikrinti Rusijos pajègų perdislokavimą ir pasirengimą kovos veiksmams. Šiuo tikslu veikia ir toliau vystoma Rusijos-Baltarusijos bendrų logistinių bazių - dvigubo bazavimosi (angl. dual basing) ir priimančiosios šalies - koncepcija. Tam pritaikoma ir modernizuojama priimančiosios šalies infrastruktūra. Vyksta abiejų šalių karinių ir civilinių institucijų, užnugario tarnybų ir logistikos struktūrų sąveikos treniruotès ${ }^{20}$. Bendra logistinè koncepcija suteikia palankias sąlygas Rusijos karinèms pajègoms operatyviai pasirengti kovos veiksmams prieš NATO.

Karinès oro bazès įsteigimo Baltarusijos Bobruisko aerodrome aktualizavimas yra akivaizdus Rusijos strateginių veiksmų pavyzdys. Nuo $2013 \mathrm{~m}$. Rusijos aukščiausioji politinè valdžia spaude Baltarusijos prezidentą realizuoti ši projektą. Kaip paskutinis (pirminiame variante Lydoje, esančioje $35 \mathrm{~km}$ nuo Lietuvos sienos) variantas buvo pasirinktas Bobruisko aerodromas, kuriame pradiniame etape galetų būti dislokuotas santykinai nedidelis pajègumas naikintuvų eskadrilè, turinti 14 lèktuvų „Su-27“ (iš jų du mokomieji) ir 4 aprūpinančius sraigtasparnius. Palyginimui Baltijos šalių oro erdvės kontrolei yra skirti tik 8 NATO šalių lèktuvai. Toks sąjungininko ketinimas dislokuoti karinius pajègumus Baltarusijoje Aleksandrui Lukašenkai, deklaruojančiam karinių pajėgų galios vystymą išimtinai savo šalies gynybai, buvo nepriimtinas. Kaip alternatyvų variantą pasiūlè sąjungininkei aprūpinti Baltarusijos karines pajègas modernia ginkluote. Šiuo atveju Rusija neaštrino problemos, nes vykstant paspartintiems integraciniams karinių pajègų procesams bei sparčiai modernizuojant savo ginkluotę ir karines greitojo reagavimo pajėgas, karinių bazių steigimas nèra būtiniausias reikalas, todèl šios problemos sprendimas buvo sèkmingai atidètas geresniems laikams. Savo ruožtu aviacijos pulkas dislokuotas Kaliningrado srityje ${ }^{21}$.

\footnotetext{
${ }^{20}$ Завершился очередной этап совместных специальных учений материально-технического обеспечения Вооруженных Сил Российской Федерации и Республики Беларусь, https://tvzvezda.ru/ news/forces/content/1774ab57743aaee0f0129f4272f133e79038f0b288f41582e48b2083ba805e3e [žiurrèta 201803 03].

${ }^{21}$ Авиабаза в Бобруйске станет „аэродромом подскока“ для авиации РФ https://charter97.org/ru/ news/2014/10/31/123744/ [žiūretta 201803 24]; Bohdan S., Moscow gives Belarus Arms and Seems to Abandon Airbase Plans, Belarus Digest, https://belarusdigest.com/story/moscow-gives-belarus-armsand-seems-to-abandon-airbase-plans/ [žiürèta 201803 28]; Вопрос российской авиабазы в Беларуси закрыт. Но у Москвы есть другие вопросы, https://naviny.by/article/20180116/1516081802-voprosrossiyskoy-aviabazy-v-belarusi-zakryt-no-u-moskvy-est-drugie [žiūréta 201804 08]; Augustis R., RusijosBaltarusijos karinès integracijos pokyčiai po Krymo aneksijos. Magistro darbas, Vilnius, 2018, p. 57-59; Алесин А., Вопрос российской авиабазы в Беларуси закрыт. Но у Москвы есть другие вопросы, https://naviny.by/article/20180116/1516081802-vopros-rossiyskoy-aviabazy-v-belarusi-zakryt-no-umoskvy-est-drugie [žiūrèta 201803 16].
} 
Dvišalio integracijos igyvendinimo pavyzdžiu galima laikyti vieningos regioninès oro erdvès gynybos sistemos sukūrimą. Nuo $2016 \mathrm{~m}$. ši sistema, anot Baltarusijos ir Rusijos valdžios oficialių pareigūnų, veikia visa apimtimi ir vykdo šias užduotis: kontroliuoja Baltarusijos oro erdvę, seka potencialius jos kryptimi judančius arba joje esančius taikinius, perduoda informaciją koviniams padaliniams, įskaitant ir Rusijos karinių oro pajėgų valdymo centrą Pamaskvèje, karinių oro pajègų štabui Sankt Peterburge ir Rusijos oro gynybos padaliniams Kaliningrado srityje ${ }^{22}$. Kaip ši sukurta bendra sistema veikia praktiškai?

Remiantis Rusijos ir Baltarusijos susitarimu dèl bendros oro erdvès gynybos, Baltarusijos segmento dalis, hipotetinio konflikto su NATO atveju, tikètina turètų atremti priešo raketų ir aviacijos puolimą, saugodama Baltarusijos teritoriją ir objektus. Tuo pačiu metu vykdytų ir Rusijos padalinių perdislokavimo ị Baltarusiją priedangą nuo oro antpuolių. Rusijos-Baltarusijos vieningai oro erdvės gynybos sistemai galimai yra priskirtos visos Baltarusijos karinių oro pajègų aviacijos bazès ir oro gynybos padaliniai, kurie yra apginkluoti baltarusių lengvatinèmis sąlygomis iš Rusijos ịsigytomis oro erdvès gynybos sistemomis, tokiomis kaip „Tor-M2E“ ir „S-300PS“. Rusijos segmentą sudaro Rusijos Vakarų karinès apygardos vadovybei pavaldūs 6-osios oro ir oro gynybos armijos (štabas Sankt Peterburge) padaliniai. Bendram junginiui yra priskirti 5 aviacijos, 10 zenitinių-raketinių ir 5 radiotechniniai ir radioelektronikos kariniai daliniai ${ }^{23}$. Taigi šis karinių pajėgų junginys organizacine prasme nèra vieningas dalinys, bet sudarytas iš dviejų komponentų, t. y. atskirai veikiančiu abiejų valstybių nacionalinių pajègų, koordinuojančių savo veiklą. „Potencialios grèsmès arba karo metu“, kaip tai numato Sąjunginès valstybės karinè doktrina, šios pajègos tampa dalimi vieningų regioninių karinių pajègų ir sukuriama bendra vadovavimo struktūra. Pagal 2009 metų sutartị, pajègoms vadovauti bendru prezidentų sutarimu skiriamas vadas, kuris taikos metu koordinuoja Rusijos ir Baltarusijos oro gynybos sistemų veiksmus. Karo metu Baltarusijos oro gynybos sistema, greičiausiai, taptų pavaldi Rusijos orokosmoso vadavietei. Šiandien susiklostè tokia praktika, kad nuo 2013 metu vieningos oro erdvès gynybos sistemos vadu skiriamas tik Baltarusijos kari-

\footnotetext{
${ }^{22}$ Спаткай Л., Региональная система ПВО Беларуси и России, http://www.bsblog.info/ [žiūrèta 201803 08].

${ }^{23}$ Соглашение между Российской Федерацией и Республикой Беларусь о совместной охране внешней границы Союзного государства в воздушном пространстве и создании Единой региональной системы противовоздушной обороны Российской Федерации и Республики Беларусь. http://www.conventions.ru/view_base.php?id=1426 [žiūrèta 201803 09]; Зверев Ю., Зачем Беларуси и России единая система ПВО. Мир перемен, http://mirperemen.net/2016/09/zachembelarusi-i-rossii-edinaya-sistemapvo/ [žiūrèta 201803 10]; Патруль на двоих, https://rg.ru/2017/10/31/ kak-rabotaet-edinaia-sistema-pvo-rossii-i-belarusi.html [žiūrèta 201803 10].
} 
nių oro pajegu vadas. Tiesa, jis vado funkcijas realiai gali eiti tik bendrų karinių pratybų, pavyzdžiui, kaip tai buvo daroma pratybų „Zapad-2017“, metu²4. Rusijos karinių oro pajęų lèktuvai Baltarusijos oro erdveje yra valdomi šios šalies valdymo centro, o informaciją ir užduotis gauna tais pačiais ryšių ir informacijos kanalais kaip ir baltarusių lakūnai. Tokia struktūra yra paprastesnè ir efektyvesnè laiko prasme, kadangi sutrumpèja komandų perdavimo ir užduočių skyrimo laikas. Ar karo metu vadovavimo struktūriniai pokyčiai bus realizuojami operatyviai, priklausys nuo išankstinio pasiruošimo.

Nepaisant to, kad iš pirmo žvilgsnio atrodytų nesudètinga užduotis buvo realizuojama du dešimtmečius, galutinị rezultatą galima vertinti kaip dar vieną karinio aljanso stiprinimo požymị, sudariusị sąlygas išplèsti bendrų veiksmų galimybes ir sukurti vadovavimo mechanizmą. Akivaizdu ir tai, kad šiandien šių karinių pajègų potencialo pakanka ne tik vykdyti gynybines funkcijas, bet koordinuojant veiksmus iš Kaliningrado ir Baltarusijos teritoriju sunaikinti taikinius Lenkijoje, Lietuvoje ir Latvijoje ir apsunkinti NATO oro pajègų veikimą Baltijos regione.

Rusija yra suinteresuota didinti karinę ịtaką Baltarusijoje, nepaisydama Lukašenkos pastangų karinị bendradarbiavimą plètoti pagal savo interesus, siekiant gauti konkrečią politinę, ekonominę ir finansinę naudą ir atsižvelgiant ì savo asmeninius interesus. Geru pavyzdžiu galètų būti 2016 m. Lukašenkos pasirašytas įsakas, pagal kurị specialiosios paskirties pajègos gali būti panaudojamos abiejų valstybių teritorijose, vykdant antiteroristines operacijas ${ }^{25}$. Tokị žingsnị galima vertinti kaip Lukašenkos apsidraudimą tuo atveju, jeigu jo režimui kiltų realus pavojus. Kita vertus, tai rodo, kad Rusija susikuria platesnių galimybių panaudoti savo karines pajègas Baltarusijos teritorijoje, nes iki šiol karinių pajėgų veikimas yra ribojamas tik karo atveju arba tik kaip bendrų pratybų elementas.

\footnotetext{
${ }^{24}$ Алесин А., ЕРС ПВО: старт, растянувшийся на годы. Беларуская прауда, http://belprauda.org/ ers-pvo-start-rastyanuvshijsya-na-gody/ [žiūrèta 201803 12]; Под единым щитом ПВО - Во славу Родины, https://vsr.mil.by/2018/08/16/pod-edinym-shhitom-pvo/ [žiūrèta 201803 13]; Гольц А., Союз с оговорками, https://newtimes.ru/articles/detail/116424/ [žiūrèta 201803 15].

25 Заквасин А., Хлусова К., Союзное войско: чего достиг военный блок России и Белоруссии за 20 лет существования, https://russian.rt.com/ussr/article/374321-rossiya-belorussiya-voennoe-sotrudnichestvo [žiūrèta 201803 17]; Российскому спецназу разрешат спецоперации на территории Беларуси https://naviny.by/article/20161212/1481558986-rossiyskomu-specnazu-razreshat-specoperacii-na-territorii-belarusi [žiūrèta 201803 18].
} 


\section{Karinis-techninis bendradarbiavimas: integracinès realybès pasiekimai ir iššūkiai}

Kaip žinoma, Rusija yra pagrindinė Baltarusijos karinės-techninės srities partnere ir tiekejja. Dèl pasirašytų, naujų ir anksčiau sudarytų ilgalaikių bendradarbiavimo sutarčiu gynybos sektoriuje Rusija išlieka pagrindine žaliavų, naujos ir atnaujintos (modernizuotos) ginkluote tiekejja Baltarusijos karinés pramonès kompleksui ir tuo pat metu pagrindine jo produkcijos pirkejja. Rusija kartais taiko Baltarusijai išskirtines lengvatines sąlygas, teikia kreditus subsidijuodama ginkluotes ịsigijimą. Tai rodo, kad pasiektas dviejų šalių karinès pramonès integracijos aukštas lygmuo. Ar galime kalbèti apie tolesnị aljanso patvarumo stiprinimą?

Pagal 2013 m. pabaigoje pasirašytą Baltarusijos ir Rusijos karinio-techninio bendradarbiavimo sutartí, iki $2020 \mathrm{~m}$. yra numatytos kelios prioritetinès kryptys: pirmoji - tai karinių įmonių bendradarbiavimas, kuriant naują ir modernizuotą ginkluotę, karinę techniką, dvigubos ir specialios paskirties produkciją, antroji - karinio-pramoninio komplekso įmonių integracija, trečioji vieningos politikos vystymas karinés produkcijos norminimo, standartizacijos ir katalogavimo srityse, ketvirtoji - Baltarusijos karinès paskirties produkcijos (paslaugų) tiekimas Rusijai ir penktoji - Rusijos karinès paskirties produkcijos (paslaugų) tiekimas Baltarusijai. Šio dokumento priede konkretizuoti darbai liudija, kad bendradarbiavimo turinys apima tradicines sritis, kuriose galima fiksuoti suintensyvejjimo požymius. Numatyta plètoti bendrus mokslinius tyrimus, kuriant naują ir modernizuotą ginkluotę, karinę techniką, tačiau tokios veiklos mastas itin mažas - tik atskiruose, pakankamai siauruose segmentuose, kaip antai, mechanizuotojo šaulių bataliono valdymo automatizavimas, naujų automobilių kūrimas, fotografavimo aparatūros kosminiams aparatams kūrimas, karinès produkcijos standartizavimas, normavimas ir katalogizavimas. Keletą reikšmingesnių veiklų numatyta karinio-pramoninio komplekso imonių integracijoje, kuriant bendrą i̇monę, surenkančią sraigtasparnius bei remontuojančią ir modernizuojančią lèktuvą „,IL-76“. Didesni planai nubrèžti plètojant bendradarbiavimą karinès ginkluotes srityje. Tiesa, Baltarusijos tiekimo Rusijai apimtis sudaro vos 10 pozicijų ir potenciali dauguma - tai komplektuojamosios detalès (taikikliams, važiuoklèms, sudètiniai elementai radiolokatoriams) ir lekktuvų „IL-76“ remonto, modernizavimo ir techninès priežiūros paslaugos pagal užsienio valstybių užsakymus. Šiuo atveju Rusija atlieka subrangovo funkciją.

Rusijos karinès produkcijos planuojama apimtis, skirta partnerei, kur 
kas solidesnè - sudaro net 33 pozicijas. Tai ne tik karinès ginkluotès ir technikos remontas bei priežiūra, šaudmenų, komplektuojamųjų detalių technikai tiekimas, personalo mokymas, bet naujos karinès ginkluotès, tokios kaip sraigtasparnių „Mi-8“, lèktuvų „Jak-130“, naikintuvų „Su-30“, bepiločių žvalgybinių aparatų, zenitinių-raketinių kompleksų „Tor-M2E“, taip pat tanko „T-72“ modernizavimas². Taigi matome kelis akivaizdžius dalykus: didžiulę disproporciją tarp karinių-pramoninių kompleksų potencialų, Baltarusijos karinès pramonès priklausymą nuo Rusijos ir jos specializaciją ị išimtinai komplektuojamųų detalių gamybą.

Reikètų atkreipti dèmesị, kad vis labiau rūpinamasi vieningoms regioninèms karininèms pajejoms skirtos infrastruktūros kūrimo projektais. Šiuo atveju turime naują programą, kurioje numatyta šiai struktūrai reikalingos bendros infrastruktūros vystymas: Rusijoje vieno aerodromo, Baltarusijoje dviejų aerodromų ir radiolokacinio centro remonto darbai, o kapitaliniai remontai kitų senos infrastruktūros objektų (ginklų ir šaudmenų sandèliai, kiti karinès paskirties pastatai) - vèlgi potenciali dauguma Baltarusijoje - 44 ir 16 Rusijos teritorijoje. Lèšos skiriamos iš Sajunginès valstybès biudžeto. Geležinkelių infrastruktūros atnaujinimo darbai taip pat susiejami su bendromis karinėmis pajëgomis, skiriant didesnes lèšas nei ankstesnei programai. Dažniausiai Rusijos finansinis indèlis gerokai viršija Baltarusijos ${ }^{27}$.

Šalia šių projektų vyksta logistinès sistemos plètra. $2017 \mathrm{~m}$. atnaujinta 2005 m. pasirašyta sutartis apie kartu abiejų šalių vykdomą regioninių pajègų aprūpinimą. Sutartyje numatyti konkretūs abiejų šalių veiksmai, siekiant užtikrinti aprūpinimą galimiems veiksmams krizès arba karo atveju. Pažymètinas papildytas šios sutarties 7-as straipsnis, kuriame numatoma, kad taikos metu Rusijos kariuomenès sandèliuose kaupiamas šaudmenų, ginkluotės, kovos technikos ir kitų materialinių vertybių atsargos „,augančios karinès grèsmès laikotarpiu“ gali būti perkeltos ị Baltarusiją. Sutartyje yra numatoma, kad esant karo padéčiai, Baltarusijos materialinè techninè bazè ir joje sukauptos

\footnotetext{
${ }^{26}$ Соглашение между Правительством Республики Беларусь и Правительством Российской Федерации о реализации Программы военно-технического сотрудничества между Республикой Беларусь и Российской Федерацией до 2020 года, http://naviny.org/2013/12/25/by4527.html [žiūrèta 201803 19]; Поротников А., Получит ли Беларусь „свой“ танк? https://www.sn-plus.com/ru/page/ politics/9176/ [žiūrèta 201803 20]; idem, Беларусь и Россия: призрачное единение, http://www.sn-plus. $\mathrm{com} / \mathrm{ru} /$ page/politics/8458/ [žiūrèta 20180320 ].

${ }^{27}$ Baltarusija skyrė 420,000,0, o Rusija - 779,991,2 rb. Программа „Совершенствование объектов военной инфраструктуры, планируемых к совместному использованию в интересах обеспечения региональной группировки войск (сил) Республики Беларусь и Российской Федерации“ на 2018-2021 гг. Baltarusija skyrė 594,623, 5, о Rusija - 1104 234, 9 rb. Программа „Развитие и совершенствование единой системы технического прикрытия железных дорог региона“на 2016-2020 гг. https://www.postkomsg.com/programs/ [žiūrèta 201803 22].
} 
atsargos yra naudojamos bendrai. Pažymètina, kad šis papildymas, esant ganétinai laisvai interpretuojamai sąvokai - „augančios karinès grèsmès laikotarpyje“ (ankščiau buvo „agresijos laikotarpyje“), suteikia Rusijai karinių pajègu persidislokavimo ị Baltarusijos teritoriją atveju disponuoti kur kas didesniais papildomais koviniais ištekliais ${ }^{28}$. Šios naujos programos byloja apie abiejų valstybių, ypač Rusijos, pastangas suaktyvinti karinę integraciją. Išsiaiškinę perspektyvinių planų turinị pereisime prie praktinio jų realizacijos aptarimo.

Apie karinio-techninio bendradarbiavimo planų vykdymą ir didelių problemų nebuvimą deklaruojama aukščiausiu valdžios lygmeniu, tačiau baltarusių ir rusų kariniai ekspertai kalba apie egzistuojančius nesutarimus, kylančius iš skirtingų politinių ir ekonominių motyvų ${ }^{29}$. Rusija su didesnemis pastangomis siekia išnaudoti nors ir nedideles Baltarusijos karinio-pramoninio komplekso potencialo galimybes, tam geriausias būdas ịsigyti pagrindines įmones, tokias kaip „Integral“, Minsko sunkiụjų vilkikių gamyklą, MAZ automobilių gamyklą, „Pelengą“ ir kitas. Baltarusijos prezidentas Lukašenka savo ruožtu siekia išsaugoti pelningai dirbančias įmones, kurios yra svarbus šalies biudžeto pajamų šaltinis, ir siekia išsaugoti galimybę turèti geresnes derybines pozicijas su Rusija. Būtent minètame karinio-pramoninio komplekso integraciniame plane iki $2020 \mathrm{~m}$. nenumatytas privatizacijos procesas, tik bendrų įmonių kūrimas, tačiau tame sąraše nèra pagrindinių Baltarusijos karinių imonių. Taigi abiejų partnerių bendradarbiavimo procesas vyksta tam tikrų prieštaringų interesų kontekste, demonstruojant viešai permanentinius nesutarimus. Rusija periodiškai demonstruoja savo taktinị siekị vis labiau ịsigalèti Baltarusijos karineje pramonèje. Baltarusijos įmonèms trukdoma laisvai konkuruoti Rusijos rinkoje dèl pelningų užsakymų ir demonstruojamas siekis surasti pamainą Baltarusijos karinei produkcijai, kaip antai, $2016 \mathrm{~m}$. aktualizuotas svarbiausios Minsko sunkiųjų vilkikų gamyklos produkcijos automobilių važiuoklių tariamas gamybos perkèlimas ị Rusijos „Kamaz“ automobilių gamyklą. Lukašenka viešai pareikalavo, kaip kompensaciją tokiu atveju, parduoti naftos verslovę. Savo ruožtu Baltarusija norètų iš Rusijos lengvatinėmis

\footnotetext{
${ }^{28}$ Соглашение между Правительством Российской Федерации и Правительством Республики Беларусь о совместном техническом обеспечении региональной группировки войск (сил) Российской Федерациии Республики Беларусь, http://www.mid.ru/foreign_policy/international_contracts/2_contract/-/storage-viewer/bilateral/page-23/51724 [žiūrèta 201803 22].

${ }^{29} \mathrm{~B}$ приоритете „Паритет“; https://vpk.name/news/250166_v_prioritete_paritet.html [žiūrèta 201803 23].
} 
sąlygomis gauti naujausių ginklų, pavyzdžiui, raketinių kompleksų „S-400“30.

Rusijai nẻra palankūs Baltarusijos savarankiški veiksmai, ieškant naujų rinkų karinei produkcijai trečiosiose šalyse (Kinija, Tailandas, Egiptas). 2015 m. Baltarusija Ukrainai pardave 294 karinès paskirties MAZ automobilius ${ }^{31}$. Kita vertus, Baltarusijos karinès įmonès rodo pirmuosius karinès produkcijos gamybos rezultatus: pirmiausia šarvuotų mašinų - kariuomenès poreikiams atidaryta „Kaiman“ serijinè gamyba, taip pat gamybos stadiją pasiekè reaktyviné sistema „Polonez ${ }^{\text {“32 }}$. Bendrame Baltarusijos technologinès priklausomybès nuo Rusijos kontekste tai tèra tik smulkios išimtys ir jų savarankiško vystymo perspektyva ganètinai silpna dèl akivaizdžios finansinių ir žmogiškụjų išteklių stokos. Kita vertus, pastaruoju metu Baltarusijos karinè pramoné suranda ir eksploatuoja nišą, atsiradusią Rusijai atsisakant senos ginkluotès. Baltarusija gan sèkmingai atlieka trečiųjų šalių turimos senos rusiškos ginkluotès modernizavimo, techninès (garantinès) priežiūros darbus, kurių jau nebedaro $\mathrm{Ru}$ sijos įmonès ir koncernai. Tai dar vienas karinès pramonès darbo segmentas, nešantis pajamas Baltarusijos biudžetui.

\section{Išvados}

Tai galima drąsiai vertinti kaip naują Rusijos-Baltarusijos karinio bendradarbiavimo stiprinimo etapą, kurio iniciatorius Rusija, tebesitęsiančio konflikto su Vakarais kontekste, siekia sustiprinti karines galias, išnaudodama ir kontroliuodama Baltarusijos karinị potencialą. Per penkerius metus aljanso patvarumą stiprino bendradarbiavimo aktyvizacija: karinès integracijos

\footnotetext{
${ }^{30}$ Belarmy news. Россия готова скупить белорусскую оборонку, http://belarmy.by/novosti/rossiyagotova-skupit-belorusskuyu-oboronku) [žiūrèta 201804 05]; Данейко Е., Сотрудничество Беларуси и России в сфере ВПК: партнеры или конкуренты?“, http://p.dw.com/p/2YXhE/ [žiūrèta 201804 05]; Поротников А., О военной организации «союзного государства», http://www.sn-plus.com/ru/ page/politics/9139/ [žiūrèta 201804 05]; Зверев Ю., Военно-техническое сотрудничество России и Беларуси: перспективы и риски, https://eurasia.expert/voenno-tekhnicheskoe-sotrudnichestvo-rossii-ibelarusi-perspektivy-i-riski [žiūrèta 201804 05]

${ }^{31}$ Bohdan S., Belarusian arms industry struggles to survive under Kremlin pressure, https://belarusdigest.com/story/belarusian-arms-industry-struggles-to-survive-under-kremlin-pressure/ [žiūrèta 2018 04 06]; Golts A., Belarus and Russia: Military Cooperation but with Different Goals, Belarusian Foreign Policy:360․ p. 93; Заяц А., Не процветаем, но $u$ не дохнем, Интеграл” интегрируют в “Российскую электронику, Новости ВПК, https://vpk.name/news/86499_ne_procvetaem_no_i_ne_dohnem_integral_integriruyut_v_rossiiskuyu_elektroniku.html [žiūrèta 201804 05].

32 Зверев Ю., «Полонезы», беспилотники и роботы: секрет успеха белорусского ВПК. Евразия Эксперт,http://eurasia.expert/polonezy-bespilotniki-i-roboty-sekret-uspekha-belorusskogo-vpk/ [žiūrèta 201804 05]; Bogdan S., Minsk silently builds a new army. Belarus Digest, https://belarusdigest.com/story/ minsk-silently-builds-a-new-army/ [žiūrèta 201804 05].
} 
tikslai yra užfiksuoti naujuose strateginio lygmens dokumentuose - karinèse doktrinose, galutinai pabaigti seni projektai (oro erdvès gynybos sistema) ir realizuojamos naujos iniciatyvos, tiksliau sakant, bandoma igyvendinti tai, kas deklaruota prieš kelis gerus dešimtmečius abiejų valstybių strateginiuose dokumentuose. Karinių pajėgų sąveikos lygmuo gerokai išaugo dèl spartaus bendrų strateginių pratybų skaičiaus augimo, todèl jų pajegumas operatyviai vykdyti bendras kovines užduotis kur kas sustiprejjo, ne tokie ryškūs kariniotechninio bendradarbiavimo intensyvinimo procesai, tačiau akivaizdūs poslinkiai vyko plètojant bendrą karinę infrastuktūrą. Tai užtikrina vieningų regioninių karinių pajègų kovinio potencialo panaudojimo ir augimo galimybes. Svarbu yra tai, kad karinio aljanso plètojimo etape Rusija gerokai išplète savo karinių pajègu panaudojimo galimybes pasiremdama Baltarusijos karinèmis pajègomis ir jos teritorija kaip placdarmu galimiems potencialiems kariniams veiksmams.

Šiame suintensyvejjusio bendradarbiavimo etape išliko nepakitęs integracijos tempus lètinantis pagrindinis veiksnys - Baltarusijos noras išlaikyti tam tikrą status quo, nepaisant aktyvaus Rusijos spaudimo. Prezidentui Lukašenkai sparčiai didejančios ekonominès ir politinès priklausomybès nuo Rusijos laikotarpiu yra gyvybiškai svarbu išlaikyti, disponuoti ir demonstruoti savarankiškos, principinès, saviems interesams atstovaujančios politikos ženklus tiek vidaus, tiek užsienio auditorijai. Kita vertus, Baltarusija yra suinteresuota strateginès karinès partnerystès perspektyva jau vien dèl to, kad pasinaudojusi karinio bendradarbiavimo mechanizmais gali stiprinti ir modernizuoti Baltarusijos karines pajejgas Rusijos sąskaita. Tai realizuoti dabartinių karinių išlaidų apimtimi Baltarusijai būtų pakankamai sudètinga, juolab kad šalis neturi jokių potencialių alternatyvų. Todèl trumpalaikeje perspektyvoje konsoliduotų personalinių politinių režimų sąlygomis karinis bendradarbiavimas labiausiai tikètina nepatirs naujų iššūkių ir bus vystomas lètos plètros kryptimi.

2019 m. gegužé 